\title{
Дослідження процесу брикетування біомаси шнековим механізмом
}

\author{
О.І. Єременко ${ }^{1}$, В.Є. Василенков, Д.Т. Руденко \\ Національний університет біоресурсів і природокористування України
}

(м. Київ, Україна) email: ${ }^{1}$ eremolex@nubip.edu.ua

\begin{abstract}
Проведено аналіз процесу шнекового брикетування рослинних матеріалів у паливо та корми. Закономірності цього явища є підґрунтям для визначення раціональних параметрів робочих органів. При конструюванні брикетних пресів необхідно розглядати деформацію біомаси з урахуванням змінення фрізичних і реологічних властивостей в момент взаємодії зі шнековим механізмом.

Суттєвою перевагою шнекового брикетування є поєднання технологічного і транспортного процесів. Вони відбуваються безперервно з певною швидкістю. Властивості дисперсної сухої біомаси обумовлюються тим, що частинки сировини розділені прошарком повітря. Через прошарки діють сили молекулярного притягання, які забезпечують суху дифузію під час брикетування. Важливим фактором є тривалість знаходження брикету в камері формуючого пристрою при певній температурі.

Визначено, що процес ущільнення біомаси шнековим механізмом до стану брикетів відбувається у три етапи. На першому етапі виникають напруги, що призводять до деформації сировини нелінійного характеру. На другому етапі зростаюче навантаження призводить до критичної комбінації напруг, коли встановлюється рівновага між внутрішніми силами опору біомаси і силами дії робочих органів. На третьому етапі подальше збільшення навантаження призводить до розвитку пластичних деформацій.

Теоретично досліджено явище ущільнення біомаси шнековим робочим органом. Отримані формули визначають зв'язок тиску в каналі шнекового механізму з його довжиною. Тиск зростає за експоненціальною залежністю в міру просування від приймального бункера до формуючого каналу. Зазначені рівняння достовірні з точністю до прийнятих допущень про сталість коефіцієнтів тертя та про справедливість моделі переміщення пресової біомаси без зворотних потоків.

Встановлено, що при відходженні матеріалу від витка шнека і збільшені поверхні тертя, сумарна величина стримуючого моменту зростає. Це призводить до відносного провертання шарів і кожний наступний шар обертається повільніше попереднього. Тому біля витка швидкість обертання біомаси найбільша, а на відстані обертання зменшується і матеріал переміщується тільки поступово.

Шнекове брикетування має істотний недолік, зокрема при збільшенні щільності брикетів, пропускна здатність преса зменшується. Це проблемне питання є напрямком подальших досліджень.
\end{abstract}

Ключові слова: процес; дослідження; брикети; біомаса; механізм; шнеки; залежності; сили; вектори; продуктивність.

Актуальність проблеми. В Україні щорічний економічно доцільний потенціал вторинної біомаси для отримання палив становить близько 24 млн т умовного палива $[1,2]$. Стратегія розвитку біоенергетики в умовах сільськогосподарських підприємств передбачає зменшення енергетичної залежності України від імпорту енергоносіїв та диверсифрікація напрямів споживання за рахунок розширення використання аграрної побічної продукції [1].

Біопаливні брикети $є$ реальною альтернативою традиційним надровим джерелам енергії для отримання тепла. Брикети з аграрної та деревної біосировини за теплотворними характеристиками 15-19 МДж/кг не поступаються бурому вугіллю, а їх екологічні параметри взагалі поза конкуренцією. Золу доцільно використовувати як добриво. Щільність брикетів становить 900$1200 \mathrm{kr} / \mathrm{M}^{3}$. На брикетування сухої біомаси витра- чається енергія, що становить близько 3-5\% енергетичного вмісту брикетів. Проте, якщо сировина на брикети вимагає сушки, то витрати енергії на виробництво зростають до $25 \%$ від енергетичного вмісту виробів. Пресування біомаси у паливні чи кормові брикети здійснюється під високим тиском 30-60 МПа в машинах з пресувальними органами шнекових, поршневих або штемпельних (ударно-механічних) типів [3, 4].

Незважаючи на багаторічний досвід застосування перспективних шнекових пресів, методики розрахунку основних параметрів та опису фізичних явищ, які відбуваються при ущільненні у брикети рослинної маси, в даний час не існує. Тому значна кількість пресових агрегатів на підприємствах працюють в режимах, що не відповідають оптимальним умовам експлуатації. Спроби експериментальним шляхом підвищити ефективність роботи брикетних машин не завжди 
призводять до позитивних результатів [4, 5]. Тому актуальність теми даної роботи безсумнівна, а очікуванні технічні результати даної інженерноконструкторської розробки сприятиме підвищенню техніко-економічних показників брикетних пресів шнекового типу.

Аналіз останніх досліджень та публікацій. Брикетування $€$ процесом зближення під дією зовнішніх сил частинок сировини з метою збільшення щільності виробу, що забезпечує міцність отриманих брикетів. Біомаса як сировина $є$ двокомпонентною дисперсною системою, що містить у собі тверду і газоподібну складові. Дисперсним середовищем у цій системі $є$ тверді органічні частинки, а дисперсною речовиною - пухирці повітря. Механічні властивості дисперсної маси обумовлюються тим, що рослинні частинки розділені прошарками повітря, через які діють сили молекулярного притягання.

Ці сили визначають міцність дисперсної біомаси у брикетах. При зміні дисперсної речовини, наприклад, при зменшенні повітряного прошарку, молекулярні притягання частинок (тобто зчеплення) збільшуються, що веде до ослаблення молекулярних сил зчеплення по ділянках та до зменшення потрібної енергії на деформацію у вигляді ущільнення при виготовлені брикетів [4-6, 7].

Щільність брикетів збільшується при збільшенні тиску пресування і зниженні вологості. При вологості сировини понад 15 \% брикети мають недостатню щільність і відповідно малу міцність. Найбільшої міцності набуває біосировина, що пресується при температурі понад $150^{\circ} \mathrm{C}$.

При меншій температурі пресування міцність продукції знижується. Верхньою межею температури пресування $є 250^{\circ} \mathrm{C}$, коли розпочинається реакція піролізу, зокрема часткове розкладання біомаси [4-6].

Необхідно витримувати пресовану сировину у формуючій порожнині під тиском протягом певного часу, щоб відбулася релаксація пружного напруження. Чим вище температура пресованої біомаси, тим менший тиск необхідний, щоб її спресувати до високої якості. При проходженні брикету по формуючому каналу на її контактній поверхні утворюється міцна плівка [3, 4, 6, 7].

Брикети поділяють за способами пресування таким чином: гідравлічний спосіб (брикети RUF); ударний спосіб (брикети NESTRO); екструдерний (шнековий) спосіб (брикети Pini\&Kay) [3, 4, 7].

Брикети з отвором у середині мають назву Pini\&Кау на честь австрійської фірми - виробника обладнання. Брикетування біомаси здійснюють (шнековими) пресами за допомогою поєднання високого тиску до 1100 бар і термічної обробки до $350^{\circ} \mathrm{C}$. Температура у формуючому каналі сприяє оплавленню поверхні брикетів, що важливо для зберігання та транспортування виробів $[4,6,8,9]$.
При брикетуванні рослинної біомаси визначають декілька етапів. На початку ущільнення шнековим робочим органом у сировині виникають напруги, що призводять до деформації сировини причому приріст деформації не пропорційний приросту напруги, що свідчить про нелінійний характер протікання процесу. При знятті навантаження спостерігається відновлення деформацій. Подальше збільшення навантаження приводить до такої критичної комбінації напруг, при якій встановлюється гранична рівновага між внутрішніми силами опору біомаси і зовнішнім навантаженням, що називається граничним напруженим станом. Подальше збільшення навантаження призводить до розвитку пластичних деформацій [2, 4, 5, 7, 8-10].

Шнекові преси мають меншу масу, ніж поршневі, оскільки відсутні масивні поршні і маховики. Продукція виходить безперервно, тому її можна розрізати на потрібні шматки. Щільність вище, ніж у поршневих пресів. Шнекові преси працюють значно тихіше, завдяки відсутності ударних навантажень. До недоліків можна віднести підвищені витрати енергії і швидкий знос конічної частини шнека [3, 4, 9].

Матеріали і методи і дослідження. Теоретичний опис руху біомаси при екструдованому формуванні паливних брикетів $€$ аналітичною основою та підґрунтям для визначення раціональних параметрів шнекового брикетного преса. При розрахунку і конструюванні машин необхідно розглядати деформацію сировинної біомаси 3 урахуванням фізико-механічних і реологічних ії властивостей, а також взаємодії зі шнековим робочим органом у процесі утворення паливних брикетів [5, 9, 10].

Різний підхід дослідників [3, 6-10] до питання руху біомаси при формуванні брикетів привів до появи декількох методів розрахунку параметрів процесу пресування шнековими робочими органами. Дані методики розрахунку ґрунтуються на наступному:

- силовій взаємодії з робочими елементами формуючої машини;

- теорії подоби.

Відповідно до прийнятої методики, заснованої на силовій взаємодії зі шнековим механізмом, розглядається рух сировинної біомаси як тіла, що не стискується, і на яке діють визначені сили 3 боку робочого органу.

Мета дослідження - підвищення ефективності виробництва біопаливних брикетів шляхом поглибленого аналізу процесу їх отримання за допомогою шнекових робочих органів та уточнення закономірностей цього процесу.

Результати дослідження. Під дією гвинтової поверхні шнека біомаса переміщується не паралельно його осі, а гвинтоподібно зі змінною 
швидкістю в осьовому і радіальному напрямках в залежності від відстані частинок маси до осі шнека, від коефіцієнта тертя і величини протитиску [10].

Припускаємо, що безпосереднє брикетування в робочій камері шнекового преса складається з двох основних процесів (рис. 1):

- подача сировинної біомаси в зону матриці 3 одночасним ущільненням (транспортний процес);

- продавлювання біомаси крізь технологічний отвір і отримання брикетів, що відповідає методу «суха екструзія» (технологічний процес);

Для шнекового брикетування характерний збіг у часі транспортного і технологічного процесів, тобто $V_{\text {тр }}=V_{\text {техн }}$.

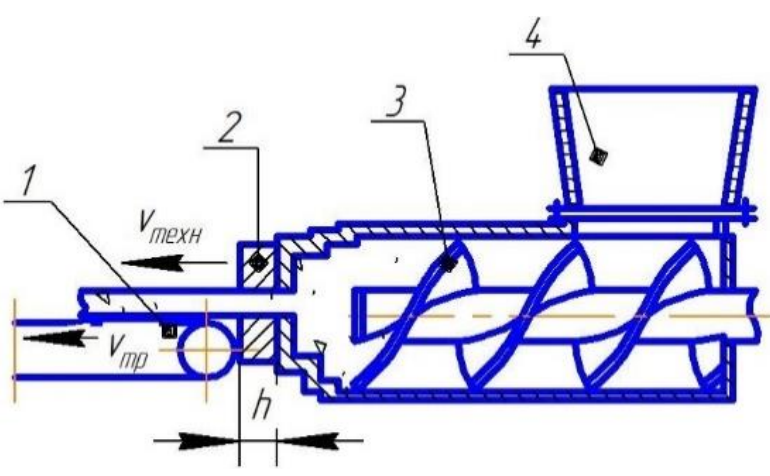

Рис. 1. Технологічна схема брикетування шнековим механізмом: 1 - стрічковий конвеєр;

2 - матриця; 3 - шнек; 4 - бункер

Пропускна здатність шнекових брикетних машин $€$ функцією технологічної $V_{\text {техн }}$ та транспортної $V_{\text {тр }}$ швидкостей та розміру матриці $h$ $\Pi_{\text {бр }}=f\left(V_{\text {техн }}, V_{\text {тр }}, h\right)$, а в розгорнутому виді -

$$
\Pi_{\text {бр }}=\frac{1}{h / V_{\text {техн }}}=\frac{1}{h / V_{\text {тр }}} .
$$

Щоб підвищити продуктивність зазначених машин необхідно збільшити транспортну швидкість $V_{\text {тр }}$, але оскільки $V_{\text {тр }}=V_{\text {техн }}$, то обмежувальним фрактором $€$ допустимі значення швидкості $V_{\text {техн }}$, яка обумовлена нормативними властивостями брикетів та сировинної біомаси.

Рішення зазначеної проблеми визначення аналітичних закономірностей шнекового брикетування повинне складатися в комплексному дослідженні залежності параметрів процесу від геометричних і кінематичних даних шнека в сполученні 3 геометричними характеристиками формуючих елементів - матриці - і з урахуванням фрізико-механічних властивостей сировинної біомаси. Сутність цієї методики полягає в наступному:

1. Визначається характеристика пресувальних органів брикетної машини, тобто залежність тиску від продуктивності і властивостей сировини.
2. Визначається оптимальна геометрія шнека і його характеристика, тобто розраховується продуктивність при різних потрібних для процесу пресування тисках, обумовлених елементами, що пресують і властивостями біомаси.

3. Визначається потужність привода і навантаження на робочі органи преса.

У гвинтовому каналі шнека біомаса рухається під впливом внутрішніх стінок циліндру робочої камери. Швидкість шарів матеріалу в міру видалення від маточини зростає, досягаючи максимуму на зовнішньому діаметрі шнека $D$. В незначному зазорі $\varepsilon$ між внутрішньою поверхнею корпусу і зовнішньою лінією шнека, швидкість зменшується від максимального значення до мінімуму на стінках циліндричної камери. В залежності від створюваного тиску та величина зазору $\varepsilon$ в кінці шнека виникає потік "виходу" спресованої маси, разом 3 цим, може утворюватись "зворотний" потік слабо ущільненої біомаси.

Модель руху без зворотних потоків (рис. 2) реалізується при пресуванні сипких і високов'язких матеріалів. Крайні випадки поведінки таких видів сировини: обертання матеріалу разом зі шнеком відносно корпусу та переміщення маси відносно шнека як гайки відносно гвинта. Другий випадок практично недосяжний навіть при наявності повздовжніх канавок на внутрішній поверхні циліндра корпусу. Як правило, реалізуються проміжні випадки руху - середні між вказаними крайніми [10].

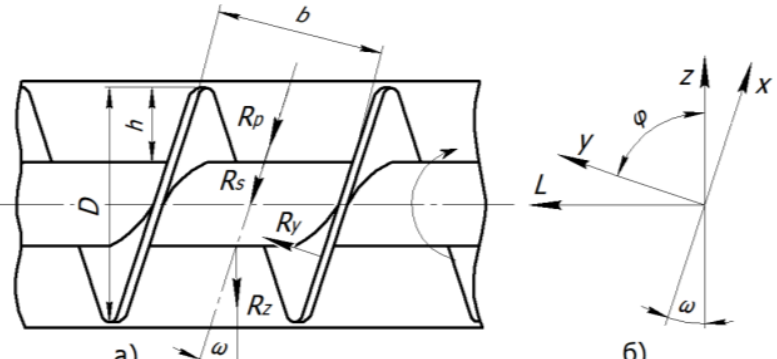

a) $\omega$

6)

Рис. 2. Схема сил, що діють в каналі шнека при переміщенні біомаси без зворотних токів:

а) розрахункова схема б) векторна схема

Сили, що діють на біомасу в каналі шнека без зворотних токів, зображені на рис. 2: $R_{y}$ - сила тиску (реакція опори) робочої поверхні шнека на біомасу, $\mathrm{H} ; R_{p}$ - сила, що обумовлена перепадом тисків вдовж канале шнека і прагне створити зворотний рух біомаси, $\mathrm{H} ; R_{s}$ - рівнодіюча сила тертя, що чине опір руху біомаси, $\mathrm{H} ; R_{z}$ - тангенціальна сила тертя біомаси об поверхню циліндричного корпусу, $\mathrm{H}$.

Рівнодіюча сила $R_{s}$ утворена такими складовими: сила тертя $R_{1}$ на торцевій поверхні витка шнека; сила тертя $R_{2}$ на робочій поверхні лопаті, 
як результат дії проекції сили $R_{z}$ на нормальну вісь лопаті шнека, що притискує біомасу; сила тертя на валу шнека $R_{3}$.

Тоді маємо: $R_{s}=R_{1}+R_{2}+R_{3}$, або в диференціальній фрормі

$$
d R_{s}=d R_{1}+d R_{2}+d R_{3} .
$$

Рівняння рівноваги діючих сил у векторній формі має вигляд:

$$
\overrightarrow{R_{y}}+\overrightarrow{R_{p}}+\overrightarrow{R_{s}}+\overrightarrow{R_{z}}=0,
$$

а в диференціальній формі -

$$
d \overrightarrow{R_{y}}+d \overrightarrow{R_{p}}+d \overrightarrow{R_{s}}+d \overrightarrow{R_{z}}=0 .
$$

Рівняння проекції сил на вісь у (рис. 2,а), яка $€$ перпендикулярна лопаті шнека, має вигляд

$$
d R_{y}+\left(d R_{z}\right)_{y}=0,
$$

де $\left(d R_{z}\right)_{y}$ - проекція тангенціальної сили тертя $d R_{z}$ на вісь у.

Рівняння проекції сил на вісь $\mathrm{x}$, яка направлена вдовж каналу шнекового механізму, має вигляд

$$
d R_{p}+d R_{s}+\left(d R_{z}\right)_{x}=0
$$

де $\left(d R_{z}\right)_{x}$ - проекція тангенціальної сили тертя $d R_{z}$ на вісь $\mathrm{x}$.

Виходячи зі схем, що рис. 2, отримуємо формулу розрахунку диференціала збільшення $\mathrm{dx}$ вдовж осі $\mathrm{x}$ :

$$
d x=\frac{d L}{\sin \varphi}
$$

де $L$ - довжина шнека, м; $\varphi$ - кут підйому гвинтової лінії шнека, град.

На підставі виразу (4) складаємо диференціальні рівняння сил тертя:

$$
d R_{1}=2 f_{s} h p d x,
$$

де $f_{s}$-коефіцієнт тертя біомаси об шнек; $h$ - глибина каналу між витками шнека, м; $p$ - тиск в даній точці каналу шнека, Па;

$$
d R_{2}=f_{s} \sin \alpha\left(d R_{z}\right)_{y},
$$

де $\alpha$ - кут між напрямком руху біомаси і площиною перпендикулярної осі шнека, град.;

$$
d R_{3}=f_{s} b p d x
$$

де $b=\pi D \sin \varphi$ - ширина шнекового каналу, м; $D$ - діаметр витка шнека, м;

$$
d R_{z}=f_{z} b p d x,
$$

де $f_{z}$ - коефіцієнт тертя біомаси об корпус;

$$
\begin{gathered}
d R_{p}=-b h d p \\
\left(d R_{z}\right)_{x}=-f_{z} b p \cos \alpha d x .
\end{gathered}
$$

Підставивши рівняння (5-10) у (1), отримуємо

$$
\begin{gathered}
d R_{s}=2 f_{s} h p d x+f_{s} f_{z} b p \sin \alpha d x+ \\
+f_{s} b p d x=f_{s}\left(2 h+b+f_{z} b \sin \alpha\right) p d x, \\
\text { а після підстановки - у (4), маємо } \\
{\left[f_{s}\left(2 h+b+f_{z} b \sin \alpha\right)-f_{z} b \cos \alpha\right] \times} \\
\times \frac{p d L}{\sin \varphi}+b h d p=0 .
\end{gathered}
$$

Розділяючи змінні в диференціальному рівнянні (12), отримуємо

$$
\frac{d p}{p}=\frac{f_{s}\left(2 h+b+f_{z} b \sin \alpha\right)-f_{z} b \cos \alpha}{b h \sin \varphi} d L .
$$

Інтегруючи обидві частини рівняння (13), а саме: ліву - за $p$, праву - за $L$, за граничною умовою $p \approx p_{0}$ при $L=0$, знаходимо

$$
\begin{gathered}
p=p_{0} \times \\
\times \exp \left(\frac{f_{s}\left(2 h+b+f_{z} b \sin \alpha\right)-f_{z} b \cos \alpha}{b h \sin \varphi} L\right),
\end{gathered}
$$

або у спрощеному вигляді

$$
p=p_{0} \exp (\theta L),
$$

причому

$$
\theta=\frac{f_{s}\left(2 h+b+f_{z} b \sin \alpha\right)-f_{z} b \cos \alpha}{b h \sin \varphi} .
$$

Отримані фоормули (13-15) визначають зв'язок тиску $p$ в каналі шнекового механізму 3 його довжиною $L$. Тиск зростає за експоненціальною залежністю у міру просування від завантажувального бункера до матриці.

Зазначені рівняння достовірні з точністю до прийнятих допущень про сталість коефіцієнтів тертя, про сталість кута $\alpha$ між направленням сили тертя біомаси о корпус преса та напрямом каналу шнека, а також про справедливість моделі пересування біомаси без зворотних потоків.

Продуктивність шнекового брикетного преса визначається на підставі визначення швидкостей руху біомаси в каналі шнека (рис. 3).

У векторній формі співвідношення між швидкостями у проекціях наступні: $\overrightarrow{v_{y}}=\overrightarrow{v_{s}}+\overrightarrow{v_{z}}$; $\overrightarrow{v_{z}}=\pi D n$, де $n$ - частота обертання шнека.

$$
\begin{gathered}
\overrightarrow{v_{x}}=\overrightarrow{v_{y}} \sin (\alpha-\varphi)= \\
=\overrightarrow{v_{y}}(\sin \alpha \cos \varphi-\cos \alpha \sin \varphi) .
\end{gathered}
$$

Провівши математичні перетворення,

$$
\frac{\overrightarrow{v_{y}}}{\sin \varphi}=\frac{\overrightarrow{v_{z}}}{\sin \alpha}
$$

$$
\overrightarrow{v_{y}}=\overrightarrow{v_{z}} \frac{\sin \varphi}{\sin \alpha}=\pi D n \frac{\sin \varphi}{\sin \alpha}
$$

отримуємо 


$$
\overrightarrow{v_{x}}=\pi D n \sin \varphi \cos \varphi(1-\operatorname{tg} \varphi \operatorname{ctg} \alpha) .
$$

Прийнявши за основу рівняння (17) щодо швидкості переміщення біомаси вдовж осі шнека, маємо вираз для визначення об'ємної продуктивності брикетного преса:

$$
Q_{\text {пр }}=\overrightarrow{v_{x}} \frac{b h}{\sin \varphi} .
$$

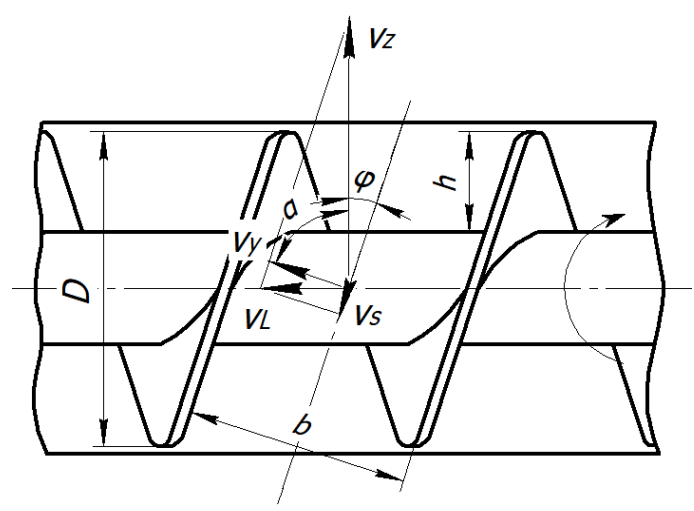

Рис. 3. Складові швидкості біомаси в каналі шнека без зворотних потоків: $v_{s}$ - швидкість вдовж каналу шнека; $v_{z}$ - швидкість у напрямку обертання шнека; $v_{y}$ - швидкість у напрямку нормалі до робочої поверхні витка шнека; $v_{x}$ - швидкість в осьовому напрямку

Вирази (17) і (18) свідчать, що продуктивність шнекового брикетування пропорціональна діаметру $D$ шнека, частоті його обертання $n$, площі прохідного перетину $b h$ шнекових каналів, а також залежить від кута підйому $\varphi$ гвинтової лінії шнека. На продуктивність суттєво може впливати форма лопатей шнека.

Особливістю шнекового брикетування $є$ те, що одні й ті ж конструкційні параметри впливають на тиск і продуктивність у протилежних напрямках. Якщо вони, наприклад, сприяють збільшенню щільності брикетів, то пропускна здатність преса зменшується. В результаті напірнорозхідна характеристика шнекового механізму $Q_{\text {пр }}=Q(p)$ наближається до зворотно пропорціональної і описується за таких умов: при $Q_{\text {пр }} \rightarrow Q_{\text {max }}, p_{\text {пр }} \rightarrow 0$; при $p_{\text {пр }} \rightarrow p_{\max }, Q_{\text {пр }} \rightarrow 0$.

Фізичне явище переміщення біомаси у пресі полягає в наступному. Сипка біомаса під дією витка шнека і його вала захоплюється і отримує обертовий рух, в результаті якого створює опір тертя біомаси об внутрішню порожнину робочої камери преса і вал шнекового механізму. Подальшому обертанню маси у пресі перешкоджають сили тертя об внутрішню порожнину нерухомого циліндра. Виникає утримуючий біомасу від обертання момент, що протидіє моменту від витка шнека.
На кожний елементарний шар біомаси через повздовжні щодо циліндра шари передаються тангенціальні сили від витка шнека. Однак, сировинна біомаса $€$ дискретним середовищем, внаслідок чого можливий зсув у площині обертання частинок одного шару відносно іншого.

За мірою віддалення від витка шнека, за причиною збільшення загальної поверхні тертя, сумарна величина стримуючого моменту зростає. Це на початку пресування призводить до провертання шарів біомаси відносно один одного. Тому кожний наступний шар обертається повільніше попереднього і обертання шарів сировинної біомаси по довжині циліндра швидко припиняється.

Таким чином, безпосередньо біля витка швидкість обертання частинок біомаси найбільша, а на деякій відстані від нього біомаса отримує обертовий момент тільки від вала шнека, а рух відбувається, в основному, поступовий. В реальному процесі біомаса з низьким коефріцієнтом тертя (наприклад, солома) може ковзати відносно витка шнека і можливе повернення ії̈ в зазор між витком і циліндром.

Висновки і перспективи. 1. Сипка біомаса під дією витка захоплюється і отримує обертовий рух, в результаті якого створює опір тертя біомаси об внутрішню порожнину робочої камери преса і вал шнекового механізму. Подальшому обертанню маси у пресі перешкоджають сили тертя об порожнину корпусу. Виникає утримуючий біомасу від обертання момент, що протидіє моменту від витка шнека.

2. Продуктивність брикетування пропорціональна діаметру $D$ шнека, частоті його обертання $n$, площі прохідного перетину $b h$ шнекових каналів, а також залежить від кута підйому $\varphi$ гвинтової лінії шнека. Особливістю шнекового брикетування $€$ те, що одні й ті ж конструкційні параметри впливають на тиск і продуктивність у протилежних напрямках. Якщо збільшують щільність брикетів, то пропускна здатність преса зменшується. В результаті напірно-розхідна характеристика шнекового механізму $Q_{\text {пр }}=Q(p)$ наближається до зворотно пропорціональної і описується за таких умов: при $Q_{\text {пр }} \rightarrow Q_{\max }$, $p_{\text {пр }} \rightarrow 0$; при $p_{\text {пр }} \rightarrow p_{\text {max }} ; Q_{\text {пр }} \rightarrow 0$.

3. Для комплексної розробки аналітичних положень шнекового механізму для отримання біопаливних брикетів необхідно:

- фрізичне явище протікання процесу брикетування конусним шнеком;

- розробити розрахункові схеми розкладу сил на циліндричній та конічній частині шнекового робочого органу;

- визначити взаємодію шнека і матриці під час брикетування;

- обґрунтувати математичні моделі робочого процесу шнекового механізму; 
- скласти графіки основних аналітичних залежностей, провести порівняльний аналіз;

- вивести розрахункові фрормули обертаючих моментів шнека;

- розрахувати шнековий механізм на міцність;

\section{Література:}

1. Гелетуха Г.Г., Железна Т.А. Стан та перспективи розвитку біоенергетики в Україні. Промислова теплотехніка. 2017, т. 39, № 2. С. 60-64.

2. Єременко О.І. Аналіз енергетичного потенціалу біомаси в Україні. Науковий вісник Національного університету біоресурсів і природокористування України. Серія: техніка та енергетика АПК. К.: НУБіП України, 2013. Вип. 185, ч. 3. C. 347-355.

3. Єременко О.І., Паянок О.В. Перспективи розвитку засобів для виготовлення паливних брикетів. Збірник наукових праць Вінницького національного аграрного університету. Серія: технічні науки. Вінниця, 2012. Вип. 11, т. 1 (65). С.327-331.

4. Гелетуха Г.Г., Желєзна Т.А.,. Драгнєв С.В. Аналіз можливостей виробництва та використання брикетів 3 агробіомаси в Україні. Аналітична записка БАУ № 20. К.: 2018. 48 с.

5. Субота С.В. Результати експериментальних досліджень роботи гвинтового прес-брикетувальника для виробництва паливних брикетів із рослинної сировини. Міжвідомчий тематичний науковий збірник Механізація та електрифікація сільського господарства. 2013. Вип. 97, т. 2. С. 40-46.

6. Лук'янець В.О., Субота С.В. Вплив параметрів ущільнення рослинної біомаси на показники якості біопаливних брикетів. Міжвідомчий тематичний науковий збірник Механізація та електрифікація сільського господарства. 2014. Вип. 99, т. 2. С. 103-113.

7. Єременко О.І., Лук'янець В.О. Дослідження та вдосконалення живильного пристрою перспективного брикетного преса. Науковий вісник Таврійського державного агротехнологічного університету. 2014. Вип. 4, т. 2. С. 146-156. URL: http://nauka.tsatu.edu.ua/e-journals-tdatu/e-index.html.

8. Семірненко С.Л. Дослідження залежності щільності брикетів із соломи озимої пшениці від деяких фракторів. Вісник Харківського національного технічного університету сільського господарства: (системотехніка і технології лісового комплексу). 2011. Вип. 111. С. 112-120.

9. Кіндзера Д.П., Атаманюк В.М., Госовський Р.Р. Дослідження процесу фрормування паливних брикетів із рослинної сировини та визначення їх характеристик. Науковий вісник Національного лісотехнічного університету України, 2013. Вип. 23. С. 138-146. http://nltu.edu.ua/nv/Archive/ 2013/23_17/138_Kin.pdf

10. Плаксин Ю.М., Малахов Н.Н., Ларин В.А. Процессы и аппараты пищевых производств / 2е изд., перераб. и доп. М.: КолосС, 2007. 760 с.
11. Єременко О.І. Метод розрахунку шнекового робочого органу для брикетування рослинних матеріалів. Технічний прогрес у тваринництві та кормовиробництві: матеріали VII-ї Всеукраїнської науково-технічної інтернет-конференції (528 грудня 2018, смт Глеваха). 2019. С. 31-34.

\section{References:}

1. Heletukha H.H., Zhelezna T.A. Stan ta perspektyvy rozvytku bioenerhetyky v Ukrayini. Promyslova teplotekhnika. 2017, t. 39, № 2. S. 60-64.

2. Yeremenko O.I. Analiz enerhetychnoho potentsialu biomasy $v$ Ukrayini. Naukovyy visnyk Natsional'noho universytetu bioresursiv i pryrodokorystuvannya Ukrayiny. Seriya: tekhnika ta enerhetyka APK. K.: NUBiP Ukrayiny, 2013. Vyp. 185, ch. 3. S. 347-355.

3. Yeremenko O.I., Payanok O.V. Perspektyvy rozvytku zasobiv dlya vyhotovlennya palyvnykh bryketiv. Zbirnyk naukovykh prats' Vinnyts'koho natsional'noho ahrarnoho universytetu. Seriya: tekhnichni nauky. Vinnytsya, 2012. Vyp. 11, t. 1 (65). S.327-331.

4. Heletukha H.H., Zhelyezna T.A.,. Drahnyev S.V. Analiz mozhlyvostey vyrobnytstva ta vykorystannya bryketiv z ahrobiomasy v Ukrayini. Analitychna zapyska BAU № 20. K.: 2018. 48 s.

5. Subota S.V. Rezul'taty eksperymental'nykh doslidzhen' roboty hvyntovoho pres-bryketuval'nyka dlya vyrobnytstva palyvnykh bryketiv iz roslynnoyi syrovyny. Mizhvidomchyy tematychnyy naukovyy zbirnyk Mekhanizatsiya ta elektryfikatsiya sil's'koho hospodarstva. 2013. Vyp. 97, t. 2. S. 40-46.

6. Luk"yanets' V.O., Subota S.V. Vplyv parametriv ushchil'nennya roslynnoyi biomasy na pokaznyky yakosti biopalyvnykh bryketiv. Mizhvidomchyy tematychnyy naukovyy zbirnyk Mekhanizatsiya ta elektryfikatsiya sil's'koho hospodarstva. 2014. Vyp. 99, t. 2. S. 103-113.

7. Yeremenko O.I., Luk"yanets' V.O. Doslidzhennya ta vdoskonalennya zhyvyl'noho prystroyu perspektyvnoho bryketnoho presa. Naukovyy visnyk Tavriys'koho derzhavnoho ahrotekhnolohichnoho universytetu. 2014. Vyp. 4, t. 2. S. 146-156. URL: http://nauka.tsatu.edu.ua/ejournals-tdatu/e-index.html.

8. Semirnenko S.L. Doslidzhennya zalezhnosti shchil'nosti bryketiv iz solomy ozymoyi pshenytsi vid deyakykh faktoriv. Visnyk Kharkivs'koho natsional'noho tekhnichnoho universytetu sil's'koho hospodarstva: (systemotekhnika i tekhnolohiyi lisovoho kompleksu). 2011. Vyp. 111. S. 112-120.

9. Kindzera D.P., Atamanyuk V.M., Hosovs'kyy R.R. Doslidzhennya protsesu formuvannya palyvnykh bryketiv iz roslynnoyi syrovyny ta vyznachennya yikh kharakterystyk. Naukovyy visnyk Natsional'noho lisotekhnichnoho universytetu Ukrayiny, 2013. Vyp. 23. S. 138-146. http://nltu.edu.ua/nv/Archive/2013/23_17/138_Kin.pdf 
10. Plaksyn YU.M., Malakhov N.N., Laryn V.A. Protsessy y apparaty pyshchevykh proyzvodstv / 2e yzd., pererab. y dop. M.: KolosS, 2007. 760 s.

11. Yeremenko O.I. Metod rozrakhunku shnekovoho robochoho orhanu dlya bryketuvannya roslynnykh materialiv. Tekhnichnyy prohres $u$ tvarynnytstvi ta kormovyrobnytstvi: materialy VII-yi Vseukrayins'koyi naukovo-tekhnichnoyi internetkonferentsiyi (5-28 hrudnya 2018, smt Hlevakha). 2019. S. 31-34.

\section{Аннотация}

\section{Исследование процесса брикетирования биомассы шнековым механизмом}

\section{А.И. Еременко, В.Е. Василенков, Д.Т. Руденко}

Проведен анализ процесса шнекового брикетирования растительных материалов в топливо и корма. Закономерности этого явления определяют рациональные параметры рабочих органов. При конструировании брикетных прессов необходимо рассматривать деформацию биомассы с учетом изменение физических и реологических свойств в момент взаимодействия со шнековым механизмом.

Существенным преимуществом шнекового брикетирования является сочетание технологического и транспортного процессов. Они происходят непрерывно с определенной скоростью. Свойства дисперсной сухой биомассы обуславливаются тем, что частицы сырья разделены прослойкой воздуха. Через прослойки действуют силы молекулярного притяжения, которые обеспечивают сухую диффузию при брикетировании. Важным фактором является продолжительность нахождения брикета в камере формирующего устройства при определенной температуре.

Определено, что процесс уплотнения биомассы шнековым механизмом до свойств брикетов происходит в три этапа. На первом этапе возникают напряжения, которые приводят сырьё к деформации нелинейного характера. На втором этапе возрастающая нагрузка приводит к критической комбинации напряжений, когда устанавливается равновесие между внутренними силами сопротивления биомассы и силами действия рабочих органов. На третьем этапе дальнейшее увеличение нагрузки вызывает развитие пластических деформаций.

Теоретически исследовано явление уплотнения биомассы шнековым рабочим органом. Полученные формулы определяют связь давления в канале шнекового механизма с его длиной. Давление возрастает по экспоненциальной зависимости по мере продвижения от приемного бункера к формирующему каналу. Указанные уравнения достоверны с точностью до принятых допущений о постоянстве коэффрициентов трения и о справедливости модели перемещения прессуемой биомассы без обратных потоков.

Установлено, что при удалении материала от витка шнека и увеличении поверхности трения, суммарная величина сдерживающего момента возрастает. Это приводит к относительному проворачиванию слоев и каждый последующий слой вращается медленнее предыдущего. Поэтому возле витка скорость вращения биомассы наибольшая, а при увеличении расстояния вращение уменьшается и материал перемещается только поступательно.

Шнековое брикетирование имеет существенный недостаток, в частности при увеличении плотности брикетов, пропускная способность пресса уменьшается. Этот проблемный вопрос является предметом дальнейших исследований.

Ключевые слова: процесс; исследование; брикеты; биомасса; механизм; шнек; зависимости; силы; векторы; производительность.

\section{Abstract \\ Research of the process of biomass briquetting by auger mechanism \\ O.I. Yeremenko, V.Ye. Vasylenkov, D.T. Rudenko}

The analysis of the process of auger briquetting of plant materials into fuel and feed is carried out. The patterns of this phenomenon are the basis for determining the rational parameters of the working bodies. When designing briquette presses it is necessary to consider deformation of biomass taking into account change of physical and rheological properties at the moment of interaction with the auger mechanism.

A significant advantage of auger briquetting is the combination of technological and transport processes. They occur continuously at a certain rate. The properties of dispersed dry biomass are due to the fact that the raw material particles are separated by a layer of air. Molecular attraction forces act through the layers, which provide dry diffusion during briquetting. An important factor is the duration of the briquette in the chamber of the forming device at a certain temperature. 
It is determined that the process of compaction of biomass by the auger mechanism to the state of briquettes occurs in three stages. At the first stage there are stresses that lead to deformation of raw materials of nonlinear nature. In the second stage, the increasing load leads to a critical combination of stresses, when an equilibrium is established between the internal forces of resistance of biomass and the forces of action of the working bodies. In the third stage, a further increase in load leads to the development of plastic deformations.

The phenomenon of biomass compaction by an auger working body is theoretically investigated. The obtained formulas determine the relationship between the pressure in the channel of the auger mechanism with its length. The pressure increases exponentially as biomass move from the receiving hopper to the forming channel. These equations are reliable to the accepted assumptions about the constancy of the friction coefficients and the validity of the model of displacement of pressurized biomass without reverse flows.

It is established that with the departure of the material from the auger coil and increased friction surfaces, the total value of the restraining moment increases. This leads to a relative rotation of the layers and each subsequent layer rotates slower than the previous one. Therefore, at the turn, the speed of rotation of biomass is the highest, and at the distance of rotation decreases and the material moves only gradually.

The auger briquetting has a significant disadvantage, in particular with increasing density of briquettes, the productivity of the press decreases. This problematic issue is the direction of further research.

Keywords: process; research; briquettes; biomass; mechanism; auger; dependencies; forces; vectors; productivity.

\section{Бібліографічне посилання/ Bibliography citation: Harvard}

Yeremenko, O. I., Vasylenkov, V. Y. and Rudenko, D. T. (2020) 'Research of the process of biomass briquetting by auger mechanism', Engineering of nature management, (3(17), pp. 15 - 22.

Подано до редакції / Received: 12.09.2020 